\title{
Interleukin 2 and Interleukin 6 Profile in Women with Spontaneous Recurrent Abortions and As Predictor of Pregnancy Outcome
}

\author{
Authors

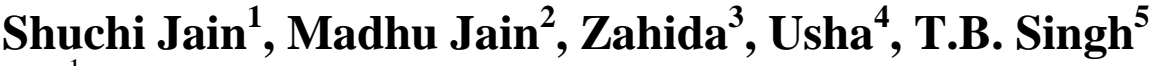 \\ ${ }^{1}$ Service Senior Resident, Email: shuchi.gyno81@gmail.com \\ ${ }^{2}$ Professor, ${ }^{3}$ Resident \\ ${ }^{1,2,3}$ Dept. of Obstetrics and Gynecology \\ ${ }^{4}$ Dept. of Pathology, ${ }^{5}$ Dept. of Biostastics \\ Institute of Medical Sciences’ Banaras Hindu University Varanasi-221005 \\ Corresponding Author \\ Prof. Madhu Jain \\ Email: drmadhujainbhu@gmail.com; Mob: 9415302988
}

\begin{abstract}
Introduction: Successful pregnancy is dependent on T helper type-2 immunity (IL6), helpful in maintaining pregnancy, while T-helper type-I activity (IL2) is responsible for deleterious effect on pregnancy. Objective: To compare the cytokines IL2 and IL6 in cases of unexplained recurrent spontaneous abortions with those who had a successful pregnancy and with those who had a consequent abortion.

Material \& Methods: Group I- The patients with recurrent spontaneous unexplained abortion in first trimester $(n=60)$ were subdivided in 2 subgroups: $a)$ who subsequently continued pregnancy $(n=40)$ and $b)$ who aborted $(n=20)$. Group II - 40 pregnant women in first trimester who delivered at term without any history of abortion were taken as controls. Blood was collected and analysed for IL2 and IL6 by ELISA kit. Parametric one way analysis of variance was used along with multiple range test (SNK) if necessary for statistical analysis.

Result: IL2 (Th1) activity was higher in recurrent spontaneous abortion group weather they continued their pregnancy or aborted in comparison to control ( $p<.0001)$. On the other hand Th2 activity was insignificantly decreased (IL6) in both the groups of recurrent aborters in comparison to control. Conclusion: Recurrent Spontaneous aborters have a definite increase in Th1 activity and decreased Th2 activity irrespective of whether they aborted or continued their pregnancy in comparison to controls.
\end{abstract}

\section{Introduction}

Primary habitual or recurrent abortions are defined as occurrence of three or more consecutive miscarriages prior to twenty weeks of gestation. The prevalence among pregnant women varies between $0.5-1 \%{ }^{1,2}$ The incidence is greater than expected by chance alone, since $10-15 \%$ of all clinically recognized pregnancies end in abortion. The causes of recurrent spontaneous abortions (RSA) are diverse. ${ }^{3}$ Halves of the recurrent miscarriages can be explained by genetic, hormonal, anatomical, metabolic abnormalities, infections or autoimmune mechanisms. Eighty percent of unexplained pregnancy failures are proposed to have an immunological background. There is an evidence that cellular immune effector mechanism is responsible for at least a proportion of 
unexplained $\mathrm{RSA}^{4,5}$. The immunological enviornment i.e. the Th1/Th2 balance might be disturbed in RSA of normal embryos. Previous investigations of Th1/Th2 immune responses during pregnancy were able to show that there is a distinct shift towards the Th2-type reactions occurs especially at the feto-maternal inferface ${ }^{6-10}$. There is evidence of Th1, type elevated concentrations of cytokines IL2, IFN-y and TNF$\mathrm{B}$ and decreased concentration of Th2 cytokine IL-10 in spontaneous abortion due to antigen and mitogen induced activation of maternal peripheral blood mononuclear cells ${ }^{11}$.

\section{Aims and Objectives}

We designed a study with the objectives (1) To compare the cytokine profiles Th1 (IL2) and Th2 (IL6) responses in RSA pregnant women who had a successful pregnancy with those RSA women who had consecutive spontaneous abortion in follow-up and with control pregnant woman (2) To assess the cut off levels of these cytokines in early pregnancy and predict the pregnancy outcome.

\section{Material and Methods \\ Subjects}

This study consisted of 60 pregnant women of less than 20 weeks gestation who had at least three previous unexplained abortions and who had been investigated for possible anatomical, endocrinological, infectious, genetic and immunological causes of abortion (Group I). Of these women, one subgroup of 40 RSA women had continued their pregnancy (Group I A). The rest 20 patients underwent spontaneous abortion (Group I B).

A similar number of healthy pregnant women of less than 20 weeks of gestation and with no history of abortion were selected as controls (Group II). Approval from Institute Ethical Committee was obtained. All patients were seen fortnightly with ultrasonography until 20 weeks of gestation and subsequently received antenatal care.

\section{Measurement of Cytokines}

Serum concentrations of interleukin 2 (IL2) and interleukin 6 (IL6) were assessed by a high sensitivity ELISA kit obtained from Couler/ Immunotech (France) which consisted of Sandwitch ELISA and manufacturer's protocols were followed. Each sample was tested by a blinded faishon. The recombinant reference cytokine samples served as positive controls for caliberation. The sensitivity of the test for IL2 and IL6 was 5 and $3 \mathrm{pg} / \mathrm{ml}$ respectively.

\section{Statistical Analysis}

$\mathrm{Z}$ test was used to test the significant difference in mean values of study and control group. The one way analysis of variance parametric test was applied to find out the significant difference among the mean levels of IL2 \& IL6 after log transformation. If this test revealed significant difference then Multiple Range test (SNK) was used to find pair wise significance difference.ROC curve technique was used to find out the cut off level of IL-2 and 6 and to predict the pregnancy outcome.

\section{Results}

The age of the patients in group 1 (RSA) was comparable to that among controls of Group II $(29.46 \pm 3.54$ Vs. $29.00 \pm 4.54, \mathrm{p}>0.05)$. The mean gravidity was $4.43 \pm 0.72$ in Group $I$ in comparison to $1.75 \pm 0.62$ in controls $(\mathrm{p}<0.001)$. The mean gestational age was $10.40 \pm 3.19$ weeks in RSA group in comparison to $10.20 \pm 3.20$ weeks in control group. Thus, both groups were comparable in respect of mean age, parity, gestational age as showed in Table I.

The measurement of IL 2 in group I B showed a significantly higher value than that of those in group I A who continued their pregnancy (498.0 \pm 412.91 Vs $30.50 \pm 21.81$, p < 0.001, Table 2).

IL 2 levels in recurrent abortion group (whether I A or I B ) were significantly higher than in controls (Group I A, $30.50 \pm 21.81$ Vs $7.36 \pm$ $10.34 \mathrm{p}<.001$ and Group 1B ,498.0 $\pm 412.91 \mathrm{Vs}$ $7.36 \pm 10.34 \mathrm{p}<.001)$ as shown in Table II, III. 


\section{JMSCR Vol||3||Issue||9||Page 7564-7569||September}

On the contrary, IL6 levels in recurrent abortion group who aborted (IB) showed insignificantly lower values $(143.50 \pm 115.65)$ in comparison to those patients who continued their pregnancy (IA, $489.75 \pm 538.97$, p 0.584) and Controls (352.96 \pm 407.42 , p 0.589). IL6 levels were much higher in Group IA and Controls although insignificantly (p 0.961). Table II \& III.
The cut off value of IL2 and IL6 were calculated through ROC curve to diagnose the patients having the risk of miscarriage. The cut off value for IL2 and IL6 were taken $\geq 5.5 \mathrm{pg} / \mathrm{m} 1$ and $\leq 150$ $\mathrm{pg} / \mathrm{ml}$ respectively which covers $96.3 \%$ and $96.4 \%$ area. The sensitivity, specificity, positive predictive value, negative predictive value and accuracy were $95 \%, 45 \%, 63.3 \%, 90 \%$ and $70 \%$ for IL-2 and $76.7 \%, 50 \%, 60.5 \%, 68.2 \%$ and $63.3 \%$ for IL-6 respectively.

Table 1: Comparative characteristics of the study groups

\begin{tabular}{|l|c|c|c|c|}
\hline \multirow{2}{*}{ Characteristics } & \multicolumn{2}{|c|}{ Study groups } & \multirow{2}{*}{ z value } & \multirow{2}{*}{ p value } \\
\cline { 2 - 4 } & $\begin{array}{c}\text { Cases } \\
(\text { Group I, } \\
\mathbf{n = 6 0})\end{array}$ & $\begin{array}{c}\text { Control } \\
(\mathbf{G r o u p ~ I I , ~} \\
\mathbf{n = 6 0})\end{array}$ & \\
\hline Age (years) & $29.46 \pm 3.54$ & $29.00 \pm 4.54$ & $\mathrm{t}=0.67$ & $\mathrm{p}>0.05$ \\
\hline Gravida & $4.43 \pm 0.72$ & $1.76 \pm 0.72$ & $\mathrm{t}=21.77$ & $\mathrm{p}<.001$ \\
\hline Parity & $0.16 \pm 0.37$ & $0.70 \pm 0.65$ & $\mathrm{t}=5.59$ & $\mathrm{p}<0.001$ \\
\hline Gestational age (weeks) & $10.40 \pm 3.19$ & $10.20 \pm 3.20$ & $\mathrm{t}=0.34$ & $\mathrm{p}>0.05$ \\
\hline Number of abortions & $3.26 \pm 0.44$ & & & \\
\hline
\end{tabular}

*Mann Whitney U test has been applied

Table 2: Distribution of Mean \pm SD of Interleukin 2 and Interleukin 6 cytokines among the study groups

\begin{tabular}{|l|c|c|c|c|c|}
\hline \multirow{2}{*}{ Variables } & \multicolumn{2}{|c|}{ Study Group } & \multirow{2}{*}{ p values } \\
\cline { 2 - 5 } & $\begin{array}{c}\text { Group I B } \\
\mathrm{n}=20\end{array}$ & $\begin{array}{c}\text { Group I A } \\
\mathrm{n}=40\end{array}$ & $\begin{array}{c}\text { Group II } \\
\mathrm{n}=60\end{array}$ & $\begin{array}{c}\text { F value } \\
\text { K.W test }\end{array}$ & \\
\hline IL2 & $\begin{array}{c}498 \pm 412.91 \\
(135-1220)\end{array}$ & $\begin{array}{c}30.50 \pm 21.81 \\
(5-80)\end{array}$ & $\begin{array}{c}7.36 \pm 10.34(0- \\
40)\end{array}$ & & \\
\hline $\log$ IL2 & $2.56 \pm 0.34$ & $1.38 \pm 0.30$ & $0.67 \pm 0.36$ & 241.34 & $<.001$ \\
\hline IL6 & $143.50 \pm 115.68$ & $489.75 \pm 538.97$ & $352.96 \pm 407.42$ & & \\
& $0-270$ & $10-1385)$ & $(20-150)$ & & \\
\hline $\log$ IL6 & $2.14 \pm 0.38$ & $2.27 \pm 0.73$ & $2.26 \pm 0.53$ & 0.38 & 0.69 \\
\hline & IL6 & $\mathrm{p}$ value & IL2 & $\mathrm{p}$ value & \\
\hline I B Vs II & 0.589 & $<.001$ & 20.61 & $<.001$ & \\
\hline I A Vs II & 0.961 & $<.001$ & 10.31 & $<.001$ & \\
\hline I B Vs I A & 0.584 & $<.001$ & 13.74 & $<.00$ & \\
\hline
\end{tabular}


Table III: Multiple range (SNK test values) non parametric test

\begin{tabular}{|l|c|c|c|}
\hline Group comparison & I B Vs I A & I B Vs II & I A Vs II \\
\hline $\log$ IL2 & $13.74^{* * *}$ & $20.61^{* * *}$ & $10.31^{* * *}$ \\
\hline $\log$ IL 6 & $0.584^{* * * *}$ & $0.589^{* * *}$ & $0.961^{* * *}$ \\
\hline & & & \\
& & & \\
$* * * \mathrm{p}<.001$ &
\end{tabular}

Table IV: Showing the various screening indices for IL2 and IL6 at a selected cut off point obtained by ROC curve.

\begin{tabular}{|l|c|c|c|c|c|c|c|}
\hline Variable & $\begin{array}{c}\text { Cut off } \\
\text { point }\end{array}$ & Area & Sensitivity & Specificity & $\begin{array}{c}\text { Positive } \\
\text { Predictive value }\end{array}$ & $\begin{array}{c}\text { Negative } \\
\text { predictive value }\end{array}$ & Accuracy \\
\hline IL2 & $\geq 5.5$ & 0.963 & 95.0 & 45.0 & 63.3 & 90.0 & 70.0 \\
\hline IL6 & $\leq 150$ & 0.642 & 76.7 & 50.0 & 60.5 & 68.2 & 63.3 \\
\hline
\end{tabular}

\section{Discussion}

Studies on human pregnancy have proposed that cellular immune mechanisms is responsible for R.S.A. The cytokine network has been suggested to be involved in positive or negative evolution of on going pregnancies ${ }^{4,11,12,13 .}$ They concluded that IL2, IFN-Y, TNF $\alpha$ cytokines were characteristic of $\mathrm{T}$ helper I (Th I) type cells which induced several cytotoxic and inflammatory reactions that had a diliterious effect on conceptus and were responsible for cell mediated immunity. On the other hand T-helper -2 cells secrete IL-4, IL5, IL6, IL10 and IL13 and are associated with humoral immunity and helpful in maintaining a normal pregnancy. Our results support this conclusion as we found that patients of RSA who went into abortion (1B) had higher values of IL2 $(p<.01)$ and insignificantly lower values of IL6 compared to those who continued their pregnancy.

Raghupathy et al compared the concentrations of T-helper 1 and T-helper 2 cytokines produced by peripheral blood mono nuclear cells from women undergoing unexplained recurrent spontaneous abortion with those produced during normal pregnancy at similar gestational age. ${ }^{12}$
Significantly high amount (p 0.004 at 24 hours of cell culture and 0.0001 after 96 hours of culture) of IL6 were found at 12 week point of normal pregnancy as compared to recurrent spontaneous aborters and the mean value of IL2 was higher in recurrent abortions than in those with normal pregnancy (p 0.04 after 24 and 0.002 after 96 hours of culture).

One important point that one needs to consider here is that unlike in our study, they took the samples after the miscarriage had taken place. Therefore, the Cytokine shift observed by them might be due to result rather than the cause of miscarriage.

Makseed et al also had results similar to our study. ${ }^{13}$ They studied Th1 and Th2 cytokine profile in recurrent aborters with successful pregnancy and subsequent abortions. Various cytokines such as IL-4, IL-5, IL-6 and IL-10 for Th2 response and IL-2, TNF- $\alpha$ and IFN-Y for TH1 were secreted by mitogen stimulated peripheral blood mononuclear cells. RSA with subsequent normal pregnancy had higher level of IL6 as compared to patients with RSA who 
underwent another abortion $(\mathrm{p}<.002)$. First trimester normal pregnancy also had higher IL6 level. IL-2 values in group 1B were higher than that in the normal pregnant women.

Wilson et al reported abnormally higher IL2 receptor levels in non pregnant women with a history of recurrent miscarriages than in women with no history of miscarriage $(\mathrm{p}<.05) .{ }^{14}$

Arlson et al reported TNFa, IL6, lupus anticoagulant and anticardiolipin antibody in women with or without a past history of RSA ${ }^{15}$. Here IL6 value was found to be highest in control group i.e. without any history of past abortion.

Contrary to our results, Bates et $\mathrm{al}^{16}$ found a greater Th1 to Th2 shift in pregnant women with RPL compared to pregnant control of similar age. Explaination for this might be the varied production of cytokines throughout pregnancy ${ }^{11,17}$ and also whether control samples were taken from pregnant women at term, during labour ${ }^{12}$ or in a nonpregnant women or in first trimester of pregnancy. ${ }^{13}$

This study may be reviewed with two caveats:

1. First the data reflected is related to the events in the maternal blood cells in periphery and not to placenta itself. It is better to find out the events related to the maternal fetal interface also.

2. This study does not show a cause and effect relationship between Th1 type reactivity and pregnancy loss. Maternal inflammatory response to a fetus that has died due to non immunological factors could well manifest as Th1 profile.

\section{Conclusion}

The IL2 level was observed to be significantly higher in pregnant women having a history of RSA with subsequent miscarriage as compared to those who had no miscarriage. The IL6 was also found to be lower in RSA who subsequently had miscarriage in comparison to those pregnant women without any abortion or RSA women who continued their pregnancy. This might help to adopt the preventive and therapeutic methods for solving this problem. This observation would throw a light for development of methods to manipulate the maternal immune system towards a Th2-type situation that would favour the successful pregnancy.

\section{Conflict of Interest: None}

Financial Source: None

Etical Clearance was obtained from Institute Ethical Committee

\section{References}

1. Adashi EY. The potential relevance of cytokines to ovarian physiology: the emerging role of resident ovarian cells of the white blood cells series. Endocr Rev 1990; 11:454-464.

2. Adashi EY, Resnick CE. Antagonistic interactions of transforming growth factors in the regulation of granulosa cell differentiation. Endocrinology 1986; 119: 1879-1881.

3. Stirrat GM. Recurrent miscarriage: its definition and epidemiology. Lancet 1990; 336: 673-675.

4. Hill JA. Immunologic factors in recurrent spontaneous abortions. In: Kurpisz M , Fernandez N, editors. Immunology of Human Reproduction. BIOS, Oxford Press; 1995. p. 401-424.

5. Raghupathy R. Th-1 type immunity is incompatible with successful pregnancy. Immunol Today 1997; 18: 478-482.

6. Lin, H., Mosmann, T.R., Guilbert, L., Tuntipopipat, S. and Wegmann, T.G. Synthesis of $\mathrm{T}$ helper 2-type cytokines at the maternal-fetal interface. J Immunol 1993;151, 4562-4573.

7. Lim, K.J., Odukoya, O.A., Ajjan, R.A., Li, T.C., Weetman, A.P. and Cooke, I.D. Profile of cytokine mRNA expression in peri-implantation human endometrium. Mol Hum Reprod 1998; 4, 77-81.

8. Piccinni MP, Beloni L, Livi C, Maggi, E., Scarselli, G. and Romagnani, S. Defective production of both leukemia inhibitory factor and type 2 T-helper cytokines by 
decidual $\mathrm{T}$ cells in unexplained recurrent abortions. Nat Med 1998; 4: 1020-1024.

9. Saito $\mathrm{S}$, Tsukaguti $\mathrm{N}$, Hasegawa $\mathrm{T}$, Michimata T, Tsuda H, Narita N. Distribution of Th1, Th2 and Th0 and the Th1/Th2 cell ratios in human peripheral and endometrial T Cells. Am. J. Reprod Immunol 1999 ; 42: 240-245.

10. Tsuda, H, Michimata T, Sakai M, Nagata K, Nakamura, M., and Saito, S. A novel surface molecule of Th 2 - and Tc2-type cells,CRTH2 expression on human peripheral and decidual $\mathrm{CD} 4^{+}$and $\mathrm{CD} 8^{+} \mathrm{T}$ cells during the early stage of pregnancy. Clin Exp Immunol 2001; 123: 105-111.

11. Marzi M, Vigano A, Trabattoni D, Villa ML, Salvaggio A, Clerici E, Clerici M. Characterization of type 1 and type 2 cytokine production profile in physiologic and pathologic human pregnancy. Clin Exp Immunol 1996; 106: 127-133.

12. Makhseed M, Raghupathy R, Azizieh F, Omu A, Al-Shamali E, Ashkanani L. Th1 and Th 2 cytokine profiles in recurrent abortions with successful pregnancy and subsequent abortions. Hum Reprod 2001; 16: 2219-2226.

13. Raghupathy R, Makhseed M, Azizieh F, Omu A, Gupta M, Farhat R. Cytokine production by maternal lymphocytes during normal pregnancy and in unexplained recurrent spontaneous abortion. Hum Reprod 2000; 15; 713-718.

14. Wilson AG, Di Giovine FS, Blakemore M, Daff GW. Single base polymorphism in the tumour necrosis factor $-\alpha$ (TNF- $\alpha$ ) gene detectable by Ncol rectriction of the PCR product. Hum Mol Genet 1992; 1:353.

15. Arslan E, Çolakoğlu M, Çelik C, Gezginç K, Acar A, Çapar M, Aköz M, Akyüre C. Serum NTF- $\alpha$, IL-6, lupus anticoagulant and anticardiolipin antibody in women with and without a past history of recurrent miscarriage Archives of Gynecology and Obstetrics, 2004; 270: 227-229

16. Bates MD, Quenby S, Takuwa K, Johnson PM, Vince GS. Aberrant cytokine production by peripheral blood mononuclear cells in recurrent pregnancy loss? Hum Reprod 2002; 17: 2439-2444.

17. Trachot-Diallot J, Gras G, Parnet-Mathieu, F. , Benveniste O, Marcé D, Roques P, Milliez J, Chaouat G, Dormont D. Modulations of cytokine expression in pregnant women. Am J Reprod Immunol 1997; 37: 215-226.

18. Makhseed M, Raghupathy R, Azizieh F Al-Azemi MM, Hassan NA, Bandar A. Mitogen induced cytokine responses of maternal peripheral blood lymphocytes indicate a differential T-helper-bias in normal pregnancy and pregnancy failure. Am J Reprod Immunol 1999 ; 42: 273281. 